\title{
NEGOTIATING AN URBAN FORM: THE STRUGGLE OF A CONCEALED KAMPUNG (KAMPONG) IN A NEW CITY DEVELOPMENT
}

\author{
DIAN ALIN MULYASARI, ANTONY SIHOMBING \& HENDRAJAYA ISNAENI \\ Department of Architecture, University of Indonesia, Indonesia
}

\begin{abstract}
Since the Indonesian government opened the opportunity for private companies to engage in the housing provision in the 1980s, many new cities have grown tremendously. Unfortunately, the growth of these cities has been followed by the emergence of a phenomenon in which the role of these developers is very dominant in urban management. This paper seeks to reveal how indigenous people who live in a small kampung (kampong) are struggling for their existence vis-à-vis a capital power. The paper provides a case of the survival of Kampung Nagrek in West BSD City Tangerang, which lies about $25 \mathrm{~km}$ to the western part of Jakarta. While most people there are displaced, this kampung exists, even though the developer has tried to conceal its existence. Employing a qualitative method, we collected data through long and intensive engagement. This study found that the coercion of physical power and the coercive economic power of developer companies have failed to conquer the kampung dwellers. It is not by the counter of physical or economic means, but through a strong social relation that those people in a marginal position will have a chance of success in negotiating its urban form.

Keywords: urban form, kampong, new city development.
\end{abstract}

\section{INTRODUCTION}

Kampung, in the Indonesian language, refers to a settlement in a village. In contemporary terms, it also relates to a settlement in the city that has similar physical characteristics to those in a village and squatter settlement [1]. The definition of kampung at the beginning of the 20 th century was an indigenous settlement. Residents still practiced traditional ways, in their everyday life, as in their desa (village), even though they were in an urban area. Meanwhile, at present, a kampung is an unstructured, unorganized, and informal settlement in relation to the broader socio-economic system. It can also be realized as a settlement in an urban area without infrastructure, planning, or urban economic networking. Poverty and poor quality of life are the prominent features of a kampung [2].

This paper uses the term kampung in referring to two meanings: 1) as a settlement in a village; and 2) as an informal settlement in the urban area. Both are used to explain the transformation of a kampung which lies in the vortex growth of the new town. Kampung Nagrek, located $27 \mathrm{~km}$ to the western part of Jakarta, is administratively part of Sampora Village, Tangerang District. Before 2008, Kampung Nagrek was a squatter settlement in the rural area. The construction of BSD City Phase II, also known as West BSD, has changed the landscape around Kampung Nagrek from rural to urban. Kampung Nagrek today is no longer a village within a rural area, but a settlement located in the urban area.

On 10 November 2015 Kompas Daily [3] wrote about city development in an article entitled "Tergagap karena mendadak kota" (Stammered as the region suddenly becoming a city). The article described how villages in the areas of new town developments are experiencing a concussion because of the tremendous changes that had been taking place over the years, which some residents refer to as "suddenly become a city". Some villages have disappeared, transformed into luxurious residential clusters along class facilities to support them. The majority of indigenous people in the vicinity of the villages have been 
marginalized to villages farther away, not only losing their homes and land, but many of them also losing their livelihoods and their futures. Those who remain in their houses are now facing a separate fence, wall, new housing, and roads. With very restricted access to their settlement, some are struggling for their existence, while the rest are only waiting for the time to move to another location.

This study tries to reveal this phenomenon from an urban form perspective. According to Castells [4], urban form is not merely a combination of materials, volume, and colour, but also a combination of uses, flows, perceptions, mental associations, and the system of representations. Urban spatial form, therefore, is a "product of basic economy and reflection process of ideological structure in symbolic configuration, elements and places".

Cortez [5] states that the primary emphasis of urban form studies is the occurrence of transformations. Urban morphology seeks to analyse the evolution of a city beginning from early development stages to its transformation later [6].

Therefore, this study places emphasis on the study of urban morphology and on the issues related to the struggle of kampung dwellers as marginal elements to have their rights in shaping their space in new city development.

In order to build a comprehensive and complex picture presented with words in detailed views obtained from respondents, this qualitative research uses a survey method. Data were collected through long and intensive engagement for about 12 months involving five key informants and 20 out of 128 household heads. Kampung dwellers, community leaders, and representatives of the government authority were interviewed, and both the routine life and significant events of the kampung were observed, while the longer history of the struggle and of long-term residents was studied through media archives and official reports.

\section{SPATIAL TRANSFORMATION OF THE STUDY AREA}

In 1976, the President of the Republic of Indonesia issued the Instruction 13/1976 concerning the regional development of the Jakarta-Bogor-Tangerang-Bekasi (Jabodetabek) which intended to reduce the pressure of population in Jakarta. Together with the construction commencement of a new toll road in the 1980s, it has stimulated the growth of a new housing area in Bogor, Tangerang, and Bekasi. After the success of Pondok Indah, the developers of housing began to spread their wings to the east and west corridor of Jakarta, namely Tangerang and Bekasi. By trying to imitate the concept of an urban form in North America [7], some new towns were developed in Botabek.

One of the most vibrant developments in Botabek is Bumi Serpong Damai (BSD City) in Tangerang. BSD City is located about $25 \mathrm{~km}$ southwest of Jakarta, and it is part of the new city of Serpong. BSD City is planned, built, and managed by PT Bumi Serpong Damai Tbk. It was established on 16 January 1984 by a consortium of shareholders. The development of BSD City officially commenced on 16 January 1989; the total area of land to be occupied by BSD is \pm 5950 hectares, covering four sub-districts (Serpong, Cisauk, Pagedangan, and Legok) and 20 villages (West Lengkong, East Lengkong, Serpong, Cilenggang, Rawabuntu, Sampora, Setu, Ciater, Buaran, Kademangan, Cisauk, Situgadung, Kadusirung, Lengkong Kulon, Pagedangan, Cijantra, Cicalengka Jatake, and Legok) [8]. According to its Master Plan, BSD City is being developed in three phases: Phase I began in 1989, covering approximately 1500 hectares; Phase II began in 2008, covering 2000 hectares; and Phase III has been planned to start in 2021 for 2450 hectares [9].

This study specifically included the case in the development of BSD City Phase II (West BSD). This phase of city construction, which began in 2008, has been altering the area from a rural to an urban one within a relatively short time. West BSD City covers three sub- 
districts: Pagedangan, Legok, and Cisauk. Formerly the area consisted of rubber plantations, rice fields, farmland, sand mining, and squatter settlements [10].

Fig. 1 shows the transformation of the region. The black areas denote the indigenous settlements (squatter settlements), while the orange areas represent the tremendous development of a new city. Although the development of a new city began in 2008, the process of kampung displacement itself was started in 2000. The image below shows how the indigenous settlement has disappeared and is replaced by the development of the new city.

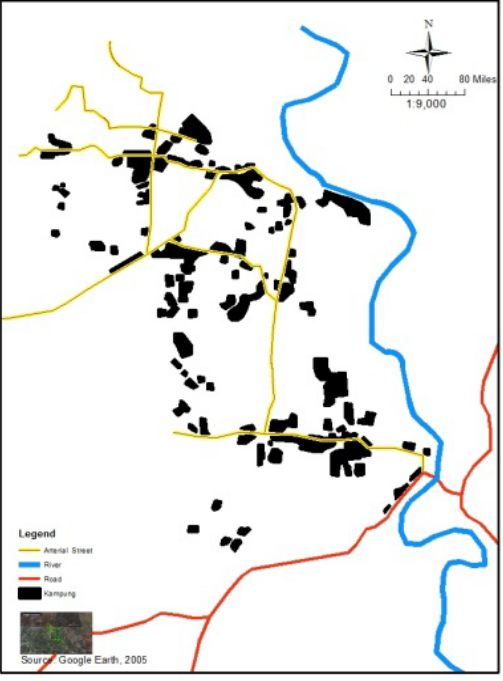

2005

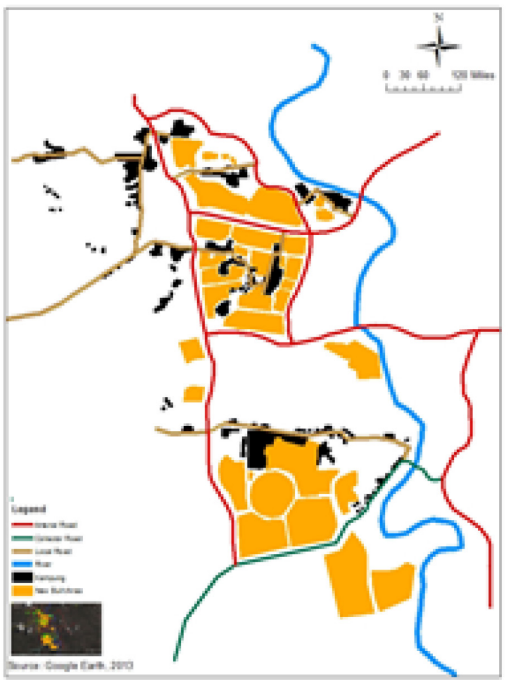

2013

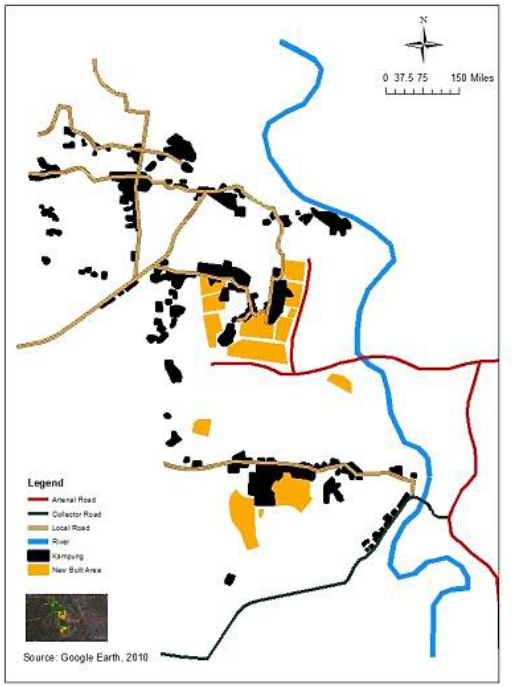

2010

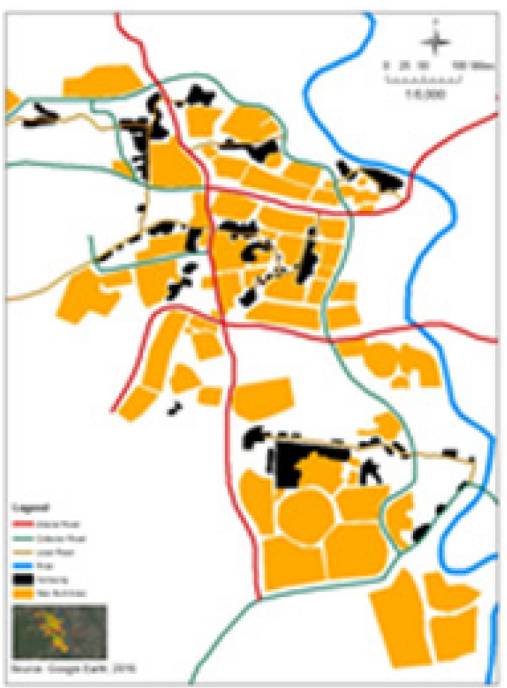

2016

Figure 1: Spatial transformation of BSD City, 2005-2016. 


\section{KAMPUNG NAGREK: AGAINST THE DISPLACEMENT}

One of the initial residential zones developed by BSD City is Foresta. It was developed in 2008 , covers 72 hectares of the area, and contains 11 residential clusters and 4.5 hectares of city forest with various facilities, such as a sports club equipped with a swimming pool and fitness centre, a jogging track, cycling paths (bike paths), as well as putting green facilities, a 3-on-3 basketball court, and gardens parks with wide pedestrian paths [11].

Right in the centre of Foresta lies a traditional settlement, namely Kampung Nagrek. Kampung Nagrek is one of the several kampongs in the development area of BSD City which have survived displacement. The location of Kampung Nagrek in the new city formation can be seen in Fig. 2. Formerly, Kampung Nagrek had a 'rural feel' and consisted of traditional settlements, rice fields, farmland, and rubber plantations. Ethnically, the neighbourhood dwellers are almost exclusively Bantenese, and residents all know each other since they constitute one extended family.

Kampung Nagrek is characterized by its strong capacity for collective action, preserving traditional customs, and the importance of paguyuban (community groups). Since its inhabitants are one big family, then the existence of informal community leaders becomes very important. The community leaders consist of sesepuh warga (elder citizens), ulama (religious scholars), and government officials. Every decision-making process, although made through rembug warga (community consensus), must be approved by community leaders.

To defend its settlement, Kampung Nagrek has been through a series of long struggles. They are dealing with a huge capital power that is supported by state forces. This phenomenon is common in many Indonesian city developments. As Firman [12] correctly points out, the vast new town development has been greatly induced by a land speculative undertaking by several private developers on the one hand, and uncontrolled land permits

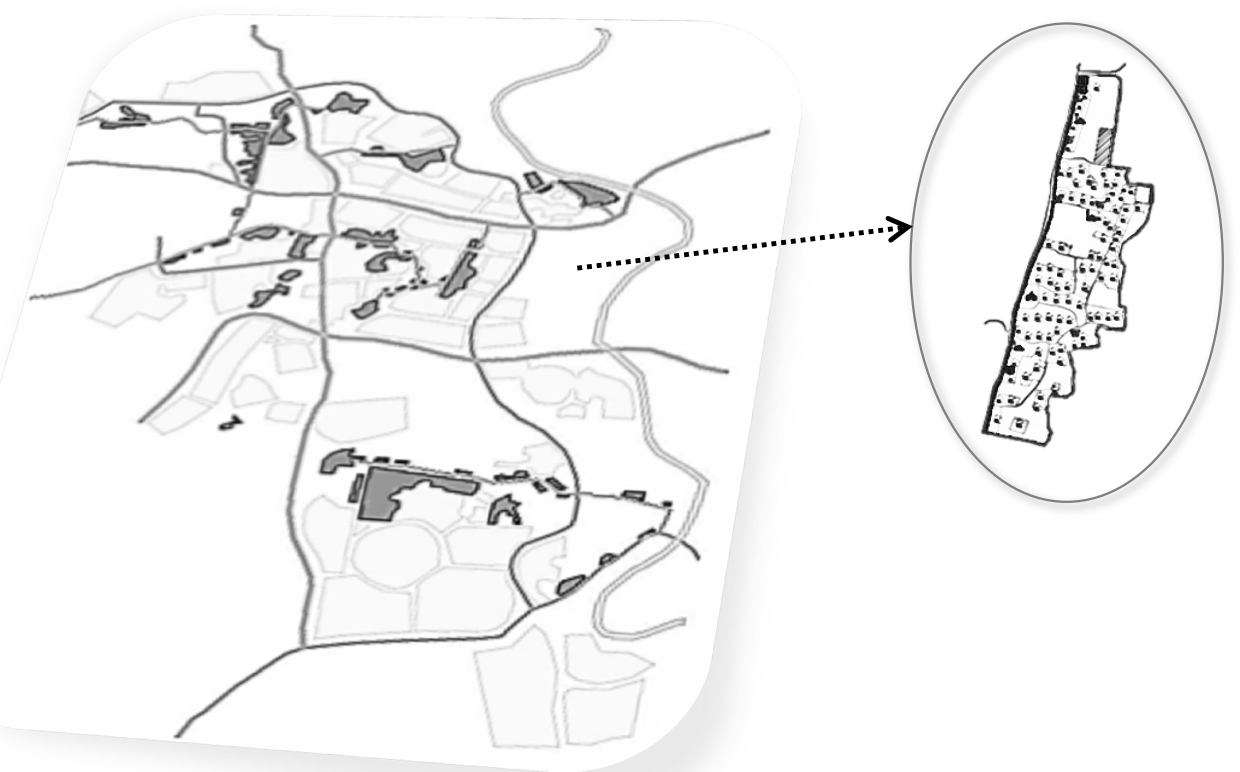

Figure 2: The location of Kampung Nagrek. 
granted by the National Land Agency (BPN) for housing development in the area on the other hand. As a result, there has been a massive land ownership transfer from the previous landowners, notably poor farmers, to the new town developers supported by the government.

The first attempts of land acquisition itself started in 2000. At this stage, the process of acquisition was quite delicate and discreetly conducted. Most people did not realize the threat to their village. They never imagined that the developer would expand its development area. People began to sell their lands, especially those outside kampung area, for various purposes.

Private developers play their role indirectly - this involves a broker company and calo tanah (individual brokers) that come from indigenous people. A study conducted by Dorleans [13] reveals the fact that the land broker receives $10 \%$ of land value for land that has an estimated market value of less than 100 million Rupiah, and 5\% for land that has a higher value. According to our interview results, there is no land price standard as most people do not possess a land rights certificate. As a result, the land price is often below market rates and determined by the bargain between the land owner and the broker.

In order to accelerate land acquisition, since mid-2004 the developers have begun a new strategy; land development permits have a legal standing to force kampung dwellers to move outside their own dwelling. The developers began to make obvious efforts in order to relocate the residents. Local governments started to get involved in this process.

The information dissemination of a new city plan was held at the head office of the village government and attended by local government representatives. The city government was represented by the Department of Spatial Planning, while camat (the head of the district level government) and kepala desa (the head of the village level government) were technically involved in directing the people. In this meeting, all community leaders were invited. They consisted of Ketua Rukun Tetangga (Head of Household Association) and Ketua Rukun Warga (the Head of the Neighbourhood Association). Both organizations are an informal self-government organization, below the village level government.

The threat of demolition hung over kampung within the BSD Master Plan. In this stage, the village government put itself as a mediator between the developer and community. Furthermore, Kepala Desa formed a team of 10 persons consisting of community representatives. Instead of being the extension of community voice, this team was actually appointed to assist people in calculating their land and assets to ensure a fair exchange. At first glance, the government seemed to take a side and protect its people; in fact, it implied the pressure from "above" that leads people to follow the developer's plan.

To this extent, the process of land acquisition was not running smoothly. The Indonesia democratic transition in 1998 significantly affected people's reactions regarding human and political rights as well as issues of voice and representation. At this point, the state was facing difficulty in having strict social control over its citizens, as occurred in the previous dictatorship regime. However, according to Dasgupta and Beard [14], the fall of Suharto's regime and the transitions to competitive elections in 1999 expanded and diversified the ways in which local elites might consolidate power. Hadiz describes the new elites as "ambitious political fixers and entrepreneurs, wily and still-predatory state bureaucrats, and aspiring and newly ascendant business groups, as well as a wide range of political gangsters, thugs, and civilian militia' [15].

The condition of local politics then became somewhat intriguing. The community raised the awareness of their rights. They began to express their voice. As a result, many resistances and protests arose within the community. On the other hand, local elites - including the government officers - began to pursue new forms of consolidating their power. Rather than displaying an authoritarian power, at this stage they presented a non-involvement role in order to disguise themselves from the community. 
Nagrek village is one of the villages that rejected the relocation proposals from developers. Based on the interview results, Kampung Nagrek dwellers refused displacement for several reasons. For the majority of dwellers, Kampung Nagrek is a place given from God through their Karuhun (ancestors). Therefore, struggling for their kampung means they worship God and honour their ancestors. Included in this case is the existence of the graves of the ancestors and the residents of the village.

Some residents also questioned their livelihood if they should be moved to another location. They argued that time during their life as one big family has run in peace and harmony. If they were separated and moved to several different locations, they might suffer and lose their peace.

In addition to these reasons, the economic motive also becomes a factor which determines the rejections of the residents. The transfer of assets between kampung dwellers and the developer allegedly will not run fairly. The developer offers residents the chance to accept the exchange via two means: land and money. They are also not willing to provide the same land area width as the land width that citizens have in their kampung. For example, if $\mathrm{Mr} \mathrm{A}$ has a land area of $1000 \mathrm{~m}^{2}$, the developer would only replace Mr A's land area with $300 \mathrm{~m}^{2}$, while the rest they will transfer to residents in cash with the price below market rates. This is deemed detrimental to the population.

Unlike other villages that reject development proposals individually, Kampung Nagrek refused the proposal collectively. The refusal was based on a consensus through a series of discussions and meetings held by the community. The community leaders took an essential role within this process. There are two community leaders who were actively involved in a representation of Kampung Nagrek dwellers. They are religious leaders and Ketua RT (the head of the household association). To accompany them, the residents appointed a former land broker. All three representatives of the citizens had their respective roles. The head of RT was assigned to connect citizens to the government, the former broker was deemed essential to facilitate communication with the developer, while religious leaders were considered persons of knowledge who have extensive knowledge of the religious, social, and governance areas.

Several times, the kampung representatives had to face a variety of pressures and threats coming from unknown parties. One local religious leader has even been taken away from his home, and was taken to a hidden place to negotiate. A similar pressure also comes from the local government through various means.

Recognizing their difficult position, residents finally agreed to be relocated to the new area, with the requirement that they remain placed in one group, with the spatial configuration that matches their current village. Given that the proposed terms of the residents were too difficult to meet, the developer, together with the government, eventually cancelled the relocation plan. This was a success for the Kampung Nagrek dwellers in negotiating their living space.

4 PUNCHING THE BERLIN, PUNCHING THE POWER OF THE DEVELOPER

Kampung Nagrek is bounded by fences and walls which separate the village from the city's residential zone, as shown in Fig. 3. Kampung dwellers name the fences and walls as Berlin. Besides acting as a boundary, the wall also serves to hide the existence of the village, as well as to ensure the security of Foresta inhabitants. It also symbolizes the power of the developer. For kampung residents, the existence of this barrier is physically, spatially, and socially disturbing; some kampung dwellers feel offended by its existence. For them, Berlin displays social distrust between the developer and residents. Others complain about the difficult access, especially for those who work in the residential area, and many others protest. 
For several years, the developer did not respond to the community's complaints. Therefore, the kampung inhabitants started to punch and break down the walls. The destruction of the wall lead to new conflicts in the relationship between the developer and the community. However, the consensus remains difficult to achieve. Each time the developer closes the hole, the community will start to reopen it. Berlin has now become a symbol of resistance. Fig. 4 shows some holes in the walls made by kampung dwellers.

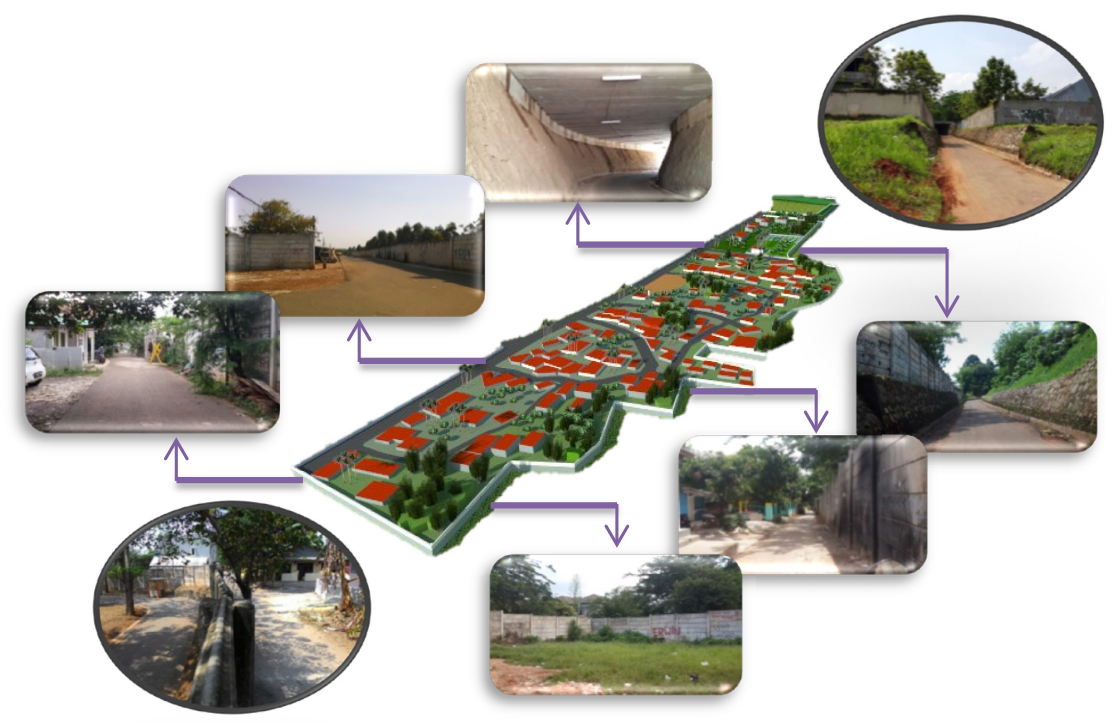

Figure 3: Berlin, a symbol of segregation and exclusion.

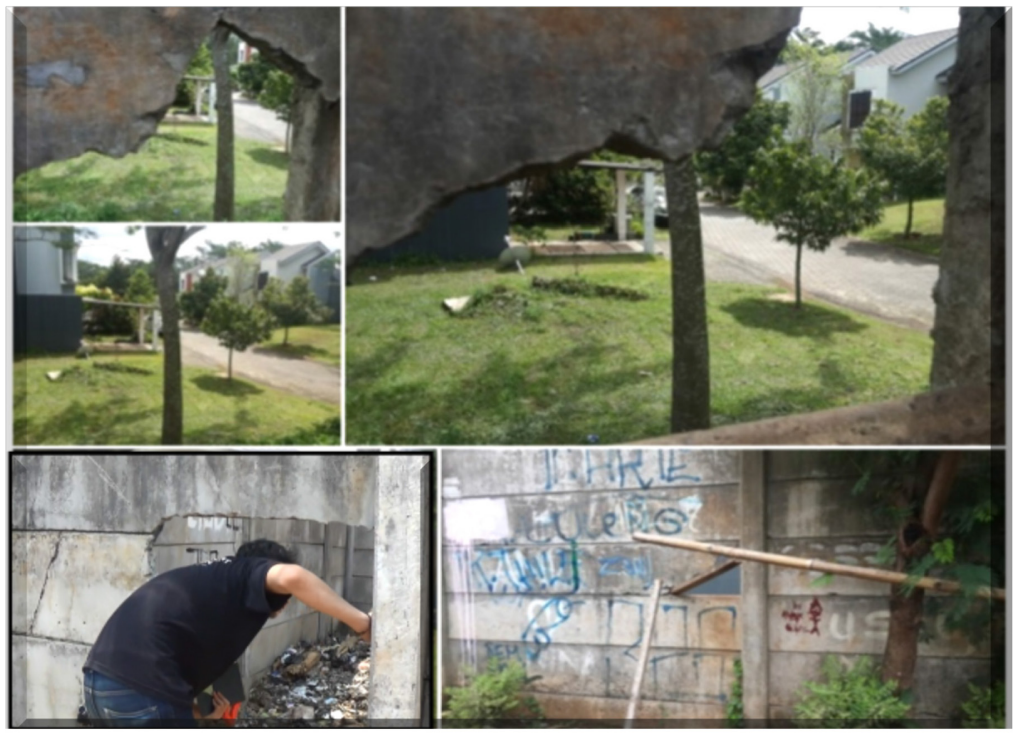

Figure 4: Some holes on the wall. 


\subsection{Economic struggle}

Rosdik is 80 years old. Previously, he was a resident of a neighbouring village. After marrying Romlah - an indigenous girl of Nagrek - he moved and settled in a house that they have now inhabited since 1975 . He bought the land area of $300 \mathrm{~m}^{2}$ from his own relative. According to Rosdik, previously, Kampung Nagrek was situated in a strategic location; it connected some villages to Serpong market, one of the important economic centres in the district of Tangerang and, therefore, many commercial activities were possible in Nagrek.

Rosdik himself felt these benefits. He and his wife sold the various daily products. Some of the items were bought from Serpong market. In addition, he also sold a variety of crops, derived both from their own land and from his neighbours' land. His wife also helped the family economy by selling food. Every day, Romlah sold gado-gado (vegetable salad) and meat soup. At the weekends, her food stall was very crowded since the road through the village was also a route taken by mountain bikers - Romlah's stall was the resting place for cyclists.

Rosdik reflects that his and Romlah's lives were very wealthy. They were able to feed their families well, their five children were able to attend school up to high-school level, he was also able to build a house with adequate materials, buy land around his house, buy a car, buy some motorcycles for his sons, and finance the pilgrimage trip with his wife.

Things began to change with the construction of the Foresta area that began in 2008. The termination of the road through the village had a very large impact on his family life. People were not longer crossing his kampung, including the cyclists and Rosdik's stalls are now facing a lack of buyers. Rosdik explains that, previously, during the weekend they would use as much as $40 \mathrm{~kg}$ of meat to be processed into soup for the cyclists; now, they use no more than $4 \mathrm{~kg}$ of meat. Warung Rosdik is not fully closed. He remains grateful for the life he has. Nowadays he relies on his children, who work outside the village.

Rosdik is just one example of kampung dwellers who, economically, was very affected by the construction of the new city. Based on this interview, we also found the population of former rice farmers and cultivators who have lost their livelihoods. Kampung Nagrek now comprises only a single row of houses, while paddy lands, fields, and orchards have been sold to developers and have been transformed into housing.

In the early years of the city development, the kampung dwellers were enjoying the proceeds of their land. Most of them used their fortune to build houses, buy vehicles, and the rest was used to meet daily consumption needs. However, this did not last long. The alteration of agricultural land to urban uses has forced kampung dwellers to find new urban employment opportunities. In the absence of adequate skills and knowledge, the dwellers cannot enter the field of decent work.

The farmers then tried to switch careers and become building labourers. Men who were young also decided to become motorcycle taxi drivers, security guards, gardeners, and so forth, while the women worked as housemaids in the housing area. By all means, the residents are still struggling for their lives and livelihoods. For them, life is like a wheel that keeps spinning. Sometimes they are positioned at the top, sometimes at the bottom. They accept the current situation as their destiny to be grateful. However, being in the homeland with the ancestors and their relatives is the best choice. Some respondents also provide signals in a shift of their perspective about the importance of education for their children. According to them, in such a situation, there is no way out other than to prepare their children with education, so that they can obtain a better job. 


\section{SUMMARY AND CONCLUSION}

This study has discussed the spatial transformations in the new city development areas of West BSD City, Tangerang, Indonesia. The transformation of urban space is a normal process in urban development. However, in Indonesian cities it has largely been uncontrolled. Land development permits have been used for the speculative trading of land. Land acquisition has then displayed the unequal relationship between developers and indigenous dwellers.

In the case of West BSD City development, there have been several major actors involved in land acquisition. The first actor is the developers who pursue to gain as much financial profits as possible out of land businesses in the area. The second is the central and local government, particularly the National Land Agency, Spatial Planning Agency, and the district and village level governments, who have facilitated land acquisition through the land permit systems and other ways. The third is the local elite that starts to diversify in consolidating their power and profits from increasing land prices. And the fourth is the kampung dwellers who are basically victims of the new city developments.

Focusing on the extent of how an indigenous settlement survives from displacement, this paper concludes that the success of the community does not merely depend on the capital and political power. It is a strong social relation that those in the marginal position have so that they will have a chance of success in negotiating its urban form.

\section{REFERENCES}

[1] Harjoko, T.Y., Urban Kampung: Its Genesis and Transformation into Metropolis, With Particular Reference to Penggilingan in Jakarta, VDM Verlag: Saarbrucken, Germany, 2009.

[2] Sihombing, A., Conflicting Images of Kampung and Kota in Jakarta: The Differences and Conflicts, and The Symbiotic Links between Kampungs and Kota, Lambert Academic Publishing, 2010.

[3] Kompas, Tergagap karena Mendadak Kota, http://print.kompas.com/baca/regional/ metropolitan/2015/11/10/Tergagap-karena-Mendadak-Kota. Accessed on: 2 Nov. 2015.

[4] Castells, M., The process of urban social change, topic. In: Cuthbert, A.R. (ed.), Designing Cities: Critical Readings in Urban Design, Blackwell Publishing, 2003.

[5] Cortez, C.E.P., Mapping Urban Form: Morphology Studies in the Contemporary Urban Landscape, TU Delft: Delft, 2009.

[6] Moudon, A.V., Urban morphology as an emerging interdisciplinary field. Urban Morphology, 1997.

[7] Cowherd, R., Hybridity, social dualism and an imagined west: the new towns in Jabotabek. Presented at Workshop of Indonesian Town Revisited, organized by the University of Leiden, 6-8 December 2000. In: Firman, T., New town development in jakarta metropolitan region: a perspective of spatial segregation. Habitat International, 28, pp. 349-368, 2004.

[8] PT BSD, Annual report Tahun 2008.

[9] PT BSD, Annual report Tahun 2010.

[10] Suryandari, R.Y., Perluasan Bandaraya Metropolitan Jakarta dan Impaknya terhadap Guna Tanah dan Corak Pekerjaan Penduduk Pinggiran: Kes Bandar Baru Bumi Serpong Damai. GEOGRAFIA Online, Malaysian Journal of Society and Space, 2 , pp. 87-104, 2006.

[11] Kompas, BSD Kembangkan Hutan Kota di Tengah Hunian, http://tekno.kompas.com/ $\mathrm{read} / 20093 / 11 / 23 / 1608311 /$ bsd.kembangkan.hutan.kota.di.tengah. hunian, Accessed on 30 May 2017, 2009. 
54 Coastal Cities and their Sustainable Future II

[12] Firman, T., New town development in Jakarta metropolitan region: A perspective of spatial segregation. Habitat International, 28, pp. 349-368, 2004.

[13] Dorleans, B., Urban land speculation and city planning problems in Jakarta before the 1998 crisis, topic. In: Nas, P.J.M. (ed.), The Indonesian Town Revisited, Southeast Asian Dynamics, Lit Verlag, 2002.

[14] Dasgupta, A. \& Beard, V.A., Community driven development, collective action and elite capture in Indonesia. Development and Change, 38(2), pp. 229-249, 2007.

[15] Hadiz, V.R., Decentralization and democracy in Indonesia: A critique of neoinstitutionalist perspectives. Development and Change, 34(4), pp. 697-718, 2004. 